\title{
Some Small Native Freshwater Fish Recommended for Mosquito and Midge Control in Ornamental Ponds ${ }^{1}$
}

\section{W. H. Kern, Jr. ${ }^{2}$}

With the increase in the popularity of ornamental ponds for raising aquatic plants, ornamental fish, and supplying water for wildlife, the potential for new mosquito breeding sites is increasing. Small insectivorous fish are a valuable tool in controlling mosquitoes and midges ("blind mosquitoes") in ponds, patio tanks, abandoned swimming pools and pools no longer maintained by their owners. Native fish seem less susceptible to wading bird predation than brightly colored ornamental fish. This publication is intended to help anyone interested in ponds or mosquito control to identify, select, collect, and stock small native fish species that would be useful in controlling mosquito populations.

\section{Mudminnow Family, Umbridae}

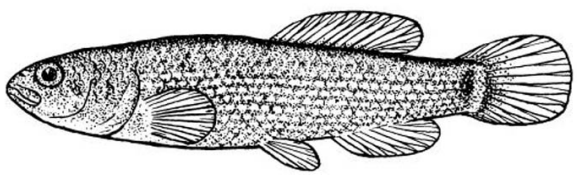

Figure 1. Eastern Mudminnow (Umbra pygmaea) to 3 inches. Dark vertical bar at base of tail. Non-game fish. Credits: Drawing by Samuel Eddy from How to Know the Freshwater Fishes 1978 /reproduced with permission of the McGraw Hill Companies.

\section{Killifish Family, Cyprinodontidae}

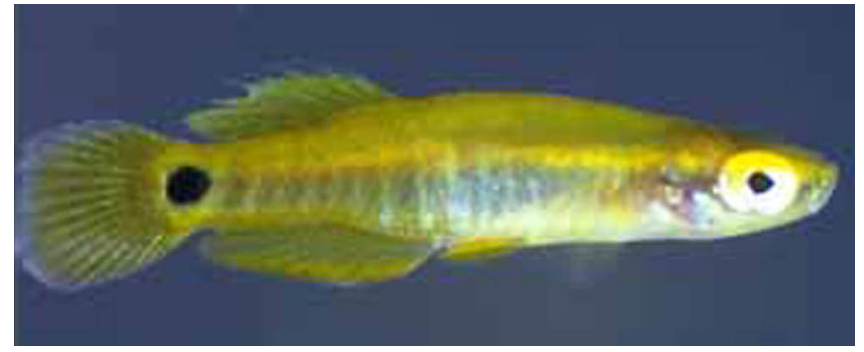

Figure 2. Pygmy Killifish (Leptolucania ommata) to 1 inch. Distinct eye spot at base of tail. Non-game fish. Credits:

Florida Fish \& Wildlife Conservation Commission (FF\&WCC) / FloridaFisheries.com

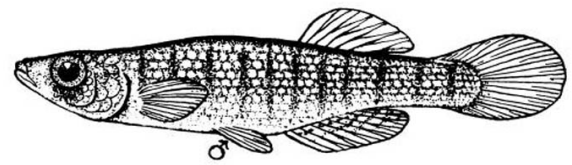

Figure 3. Lined Topminnow (Fundulus lineolatus) to $21 / 2$ inches. A surface-inhabiting minnow (topminnow) with vertical lines on their sides. Non-game fish Credits: Samuel Eddy /McGraw Hill

1. This document is Fact Sheet ENY-670, a series of the Entomology and Nematology Department, Florida Cooperative Extension Service, Institute of Food and Agricultural Sciences, University of Florida. Publication date: August 2004. Please visit the EDIS Website at http://edis.ifas.ufl.edu.

2. W. H. Kern, Jr., assistant professor, Entomology and Nematology Department, Ft. Lauderdale Research and Education Center, Cooperative Extension Service, Institute of Food and Agricultural Sciences, University of Florida, Ft. Lauderdale, FL.

The Institute of Food and Agricultural Sciences (IFAS) is an Equal Opportunity Institution authorized to provide research, educational information and other services only to individuals and institutions that function with non-discrimination with respect to race, creed, color, religion, age, disability, sex, sexual orientation, marital status, national origin, political opinions or affiliations. U.S. Department of Agriculture, Cooperative Extension Service, University of Florida, IFAS, Florida A. \& M. University Cooperative Extension Program, and Boards of County Commissioners Cooperating. Larry Arrington, Dean 


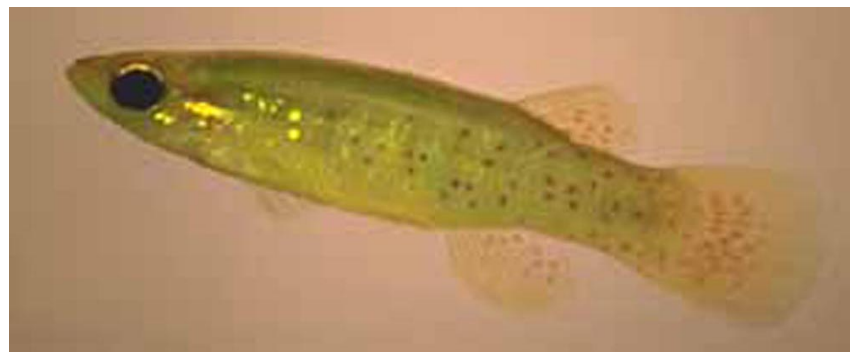

Figure 4. Golden Topminnow (Fundulus chrysotus) to 2 $1 / 2$ inches. Greenish surface-inhabiting minnow (Topminnow) with brilliant gold flecks on their sides. Non-game fish. Credits: FF\&WCC / FloridaFisheries.com

\section{Live Bearer or Guppy Family, Poecilidae}

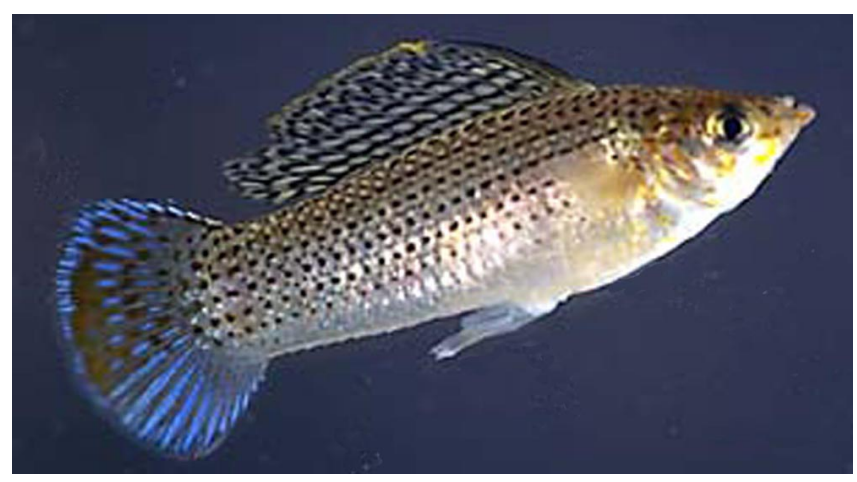

Figure 5. Sailfin Molly (Poecilia latipinna) Male to 3 inches. Rows of small dots on the sides forming lines. Dorsal fin of males much larger than those of females. Non-game fish. Credits: FloridaFisheries. com (FF\&WCC)

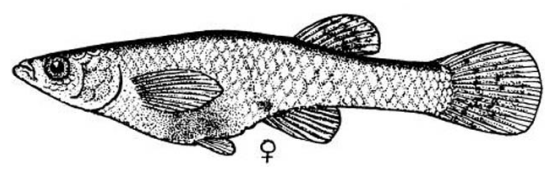

Figure 6. Eastern Mosquitofish (Gambusia holbrooki) female to $11 / 2$ inches. Plain little fish with two stripes on the tail fin. Non-game fish. Excellent mosquito-controlling species. Credits: Samuel Eddy, McGraw Hill

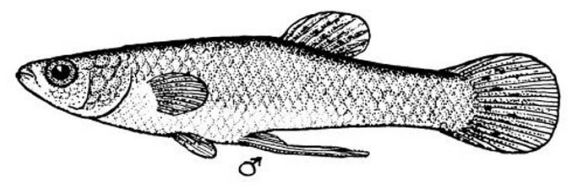

Figure 7. Eastern Mosquitofish (Gambusia holbrooki) male to 3/4 inch. Credits: Samuel Eddy, McGraw Hill

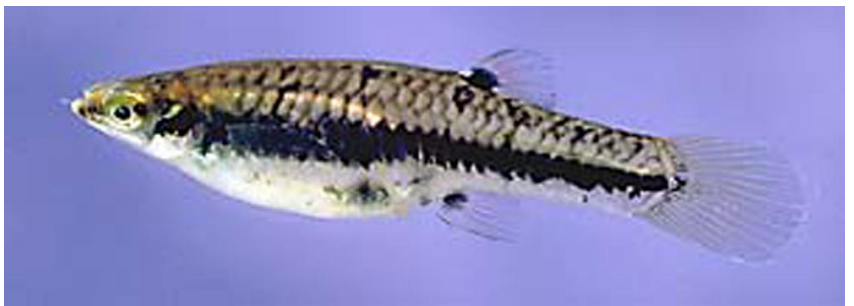

Figure 8. Least Killifish (Heterandria formosa) to 1 inch. Three black spots at the bases of the dorsal, anal, and caudal fins. Dark stripe along side. Non-game fish. One of the best mosquito controlling species. Credits: FloridaFisheries. com (FF\&WCC)

\section{Sunfish Family, Centrarchidae}

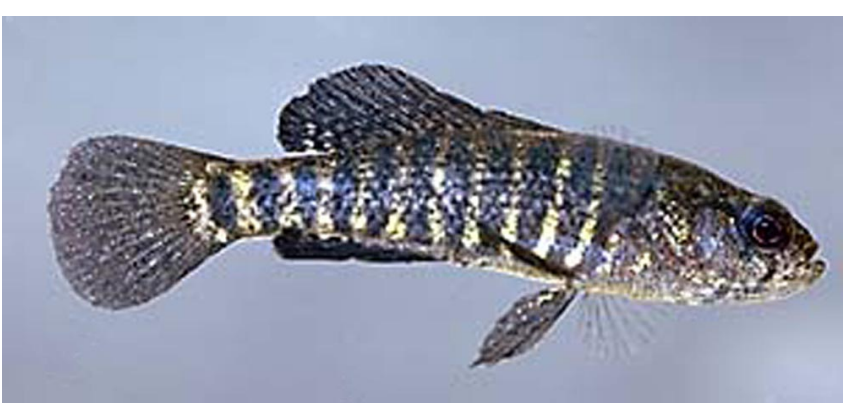

Figure 9. Banded Pygmy Sunfish Pygmy Sunfish (Elassoma zonatum) to $11 / 2$ inch. Non-game fish. Credits: FloridaFisheries. com (FF\&WCC)

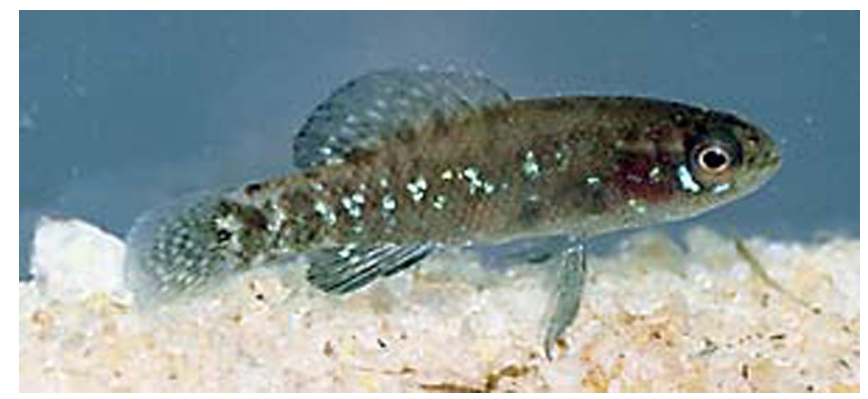

Figure 10. Everglades Pygmy Sunfish, (Elassoma evergladei) to $11 / 2$ inch. Non-game fish. Credits: FloridaFisheries. com (FF\&WCC) 


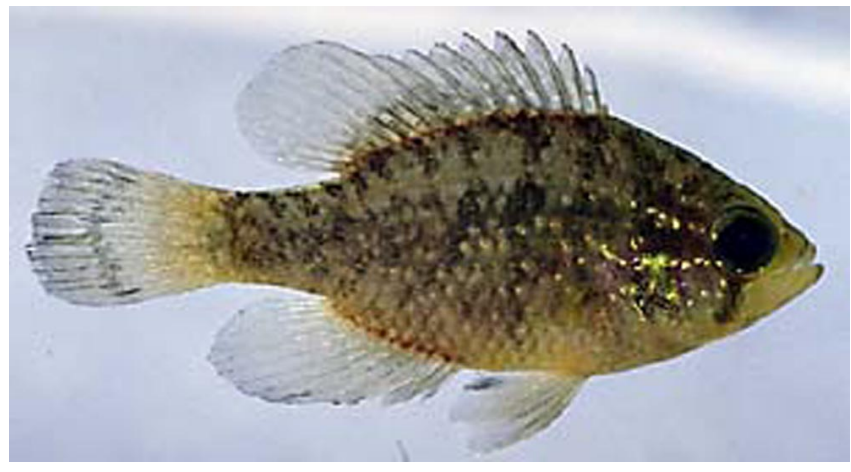

Figure 12. Bluespotted Sunfish (Enneacanthus gloriosus) to 3 inches. Bright blue flecks on the sides and fins. Non-game fish. Credits: FloridaFisheries. com (FF\&WCC)

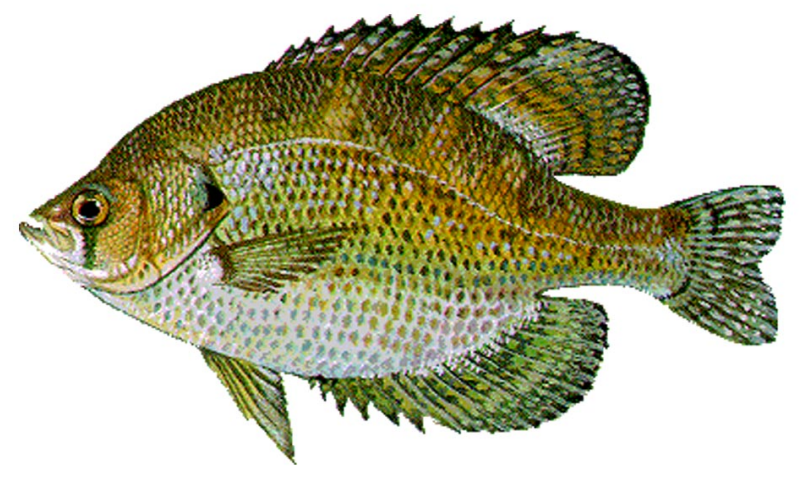

Figure 13. Flier (Centrarchus marcopterus) to 6 inches. Dorsal and anal fin nearly symmetrical. Brown spots on each scale appear as rows of dots on the sides. Game fish with collection and bag limits. Credits: Duane Raver, Jr., USFWS

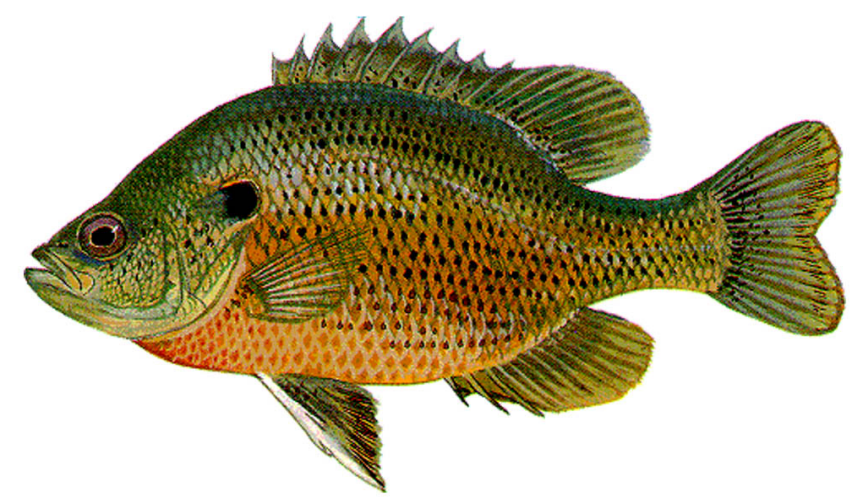

Figure 14. Spotted Sunfish or Stumpknocker (Lepomis punctatus) to 6 inches. Gill cover with a blue spot, no vertical bars, and brown spots on scales looking like rows of dots. Game fish with collection and bag limits. Credits: Duane Raver, Jr. / USFWS

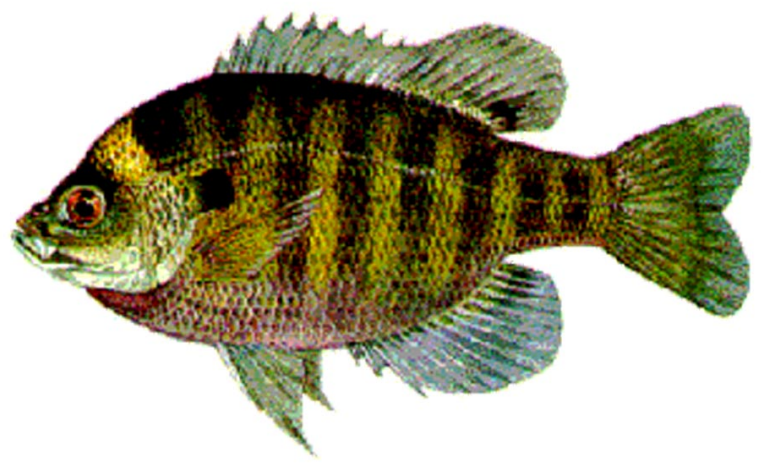

Figure 15. Bluegill or Bream (Lepomis macrochirus) to over 10 inches. Vertical bars on body and a dark spot on the rear edge of the soft dorsal fin. Game fish with collection and bag limits. Credits: Duane Raver, Jr., USFWS

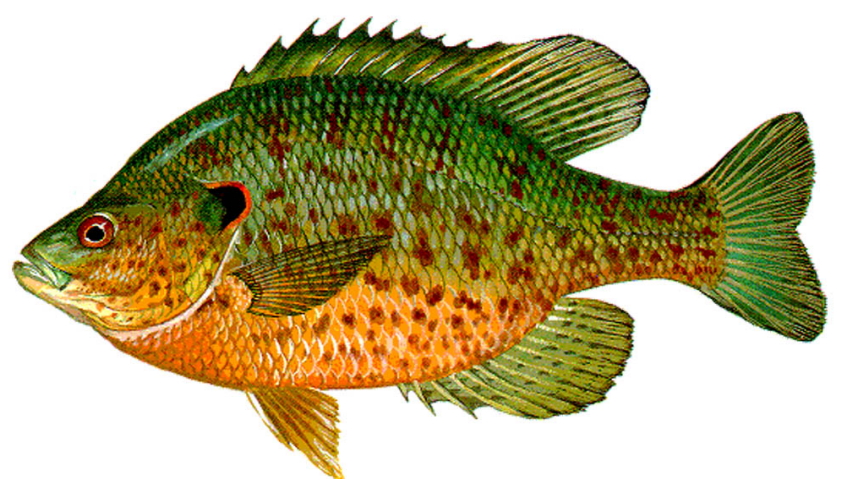

Figure 16. Redear Sunfish or Shellcracker (Lepomis microlophus) to 10 inches. Red edge to gill cover spot. Game fish with collection and bag limits. Credits: Duane Raver, Jr., USFWS

\section{Collecting}

This is not intended as a comprehensive list of all mosquito predators. Most of these fish are common and available in local ponds, canals, ditches, lake edges, or creeks. Your mosquito control district may rear some of these fish for mosquito control and may make them available to pond owners upon request. Check with your local mosquito control district office for availability. 
Collecting your own fish is part of the fun of having a pond. Most of these species are not game fish and may be collected with a seine, dip net, lift net, minnow trap, or barbless hook. Panfish species, primarily the sunfish are protected as game fish and only 50 may be collected individually or collectively per day. Only small sunfish (immature individuals or small species) are good mosquito predators. Small game fish or panfish include bluegill, redear sunfish, warmouth, redbreast sunfish, spotted sunfish, flier, mud sunfish, and longear sunfish. Game fish may only be taken by hook and line (use barbless hooks if collecting for your pond). Sunfish over three inches long are more likely to feed on other mosquito predators rather than mosquitoes.

Small non-game fish (including mosquito fish, least killifish, and minnows) may be collected using:

- Cast nets having a stretched mes size of not greater than 1 inch.

- Minnow dip nets not more than 4 feet in diameter (Figure 17).

- Minnow seines having a stretched mesh not greater than 1 inch, length not more than 20 feet and a depth not more than 4 feet.

- Minnow traps (Figure 18) not more than 24 inches in length and 12 inches in diameter, witha funnel entrance not more than 1 inch in spread.
Contact the Florida Fish and Wildlife Conservation Commission or your state Department of Natural Resources for more information about license requirements and license exemptions. If the fish are to be sold, then a Florida Resident Commercial Fishing License or a commercial freshwater fishing license from your state is required.

Only collect as many fish as you can safely transport and stock in your pond. As a general rule, stock mosquito fish at a maximum of one fish per every 2-5 gals. (20-50 mosquito fish in a 100 gal. pond). Larger fish should be stocked at lower rates (one small sunfish for each 50-100 gal.). Collect and transport fish when it is cooler. Keep the containers in the shade. Transport in an air-conditioned vehicle. Keep the water temperature in the $70-80^{\circ} \mathrm{F}$ range. Do not overload the transport containers. Fish gulping air at the surface are suffering from low oxygen stress and should be installed in the new pond as soon as possible. Once in the pond, resist the urge to feed the fish. Overfeeding will only encourage growth of algae and may cause the fish to overpopulate the pond creating water quality problems. The fish will find enough to eat with the small insects and other invertebrates living or falling into the pond.
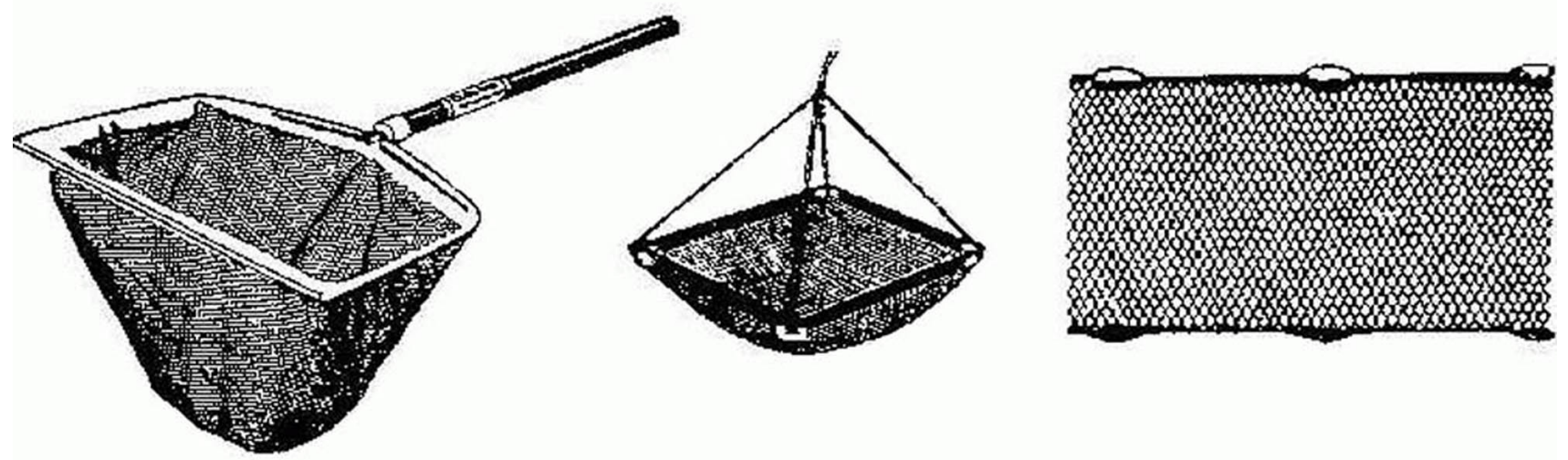

Figure 17. Dip nets, lift nets and seines are effective for catching small fish.

Collecting fish to stock in ponds requires a

Freshwater Fishing License unless the person collecting the fish is less than 16 or is 65 or older. 

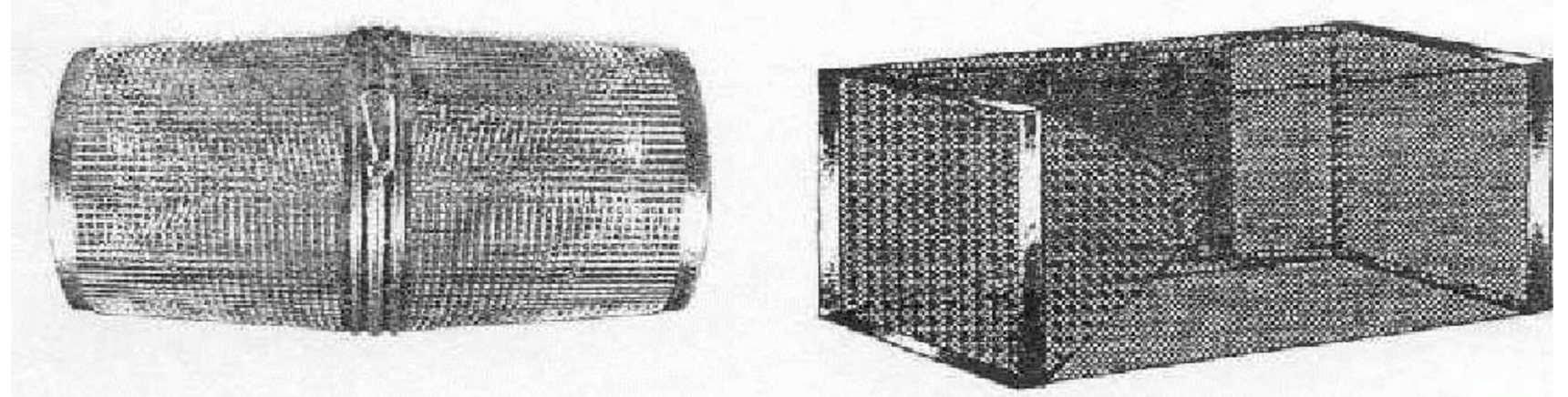

Figure 18. Minnow traps baited with bread are useful for collecting many types of small fish.

\section{Acknowledgements}

The fish drawings and photos are courtesy of the Florida Fish \& Wildlife Conservation Commission (FF\&WCC) and the US Fish \& Wildlife Service or reproduced with the permission of the McGraw-Hill Publishing Company.

\section{Selected References}

Eddy, S. and J. C. Underhill. 1978. How to know the freshwater fishes. Third edition. Wm. C. Brown Company Publishers, Dubuque, Iowa. 215 pp.

The Florida Fish and Wildlife Conservation Commission freshwater fisheries web site to Fish ID and Biology.

http://floridafisheries.com/fishes/index.html

Raver, Jr., Duane. Duane Raver Art - Freshwater Fish Collection. U.S. Fish and Wildlife Service. 